\title{
ANALYSIS OF DETERMINATION OF THE IMPLEMENTATION ACCRUAL-BASED ACCOUNTING STANDARDS IN LHOKSEUMAWE REGENCY
}

\author{
${ }^{1 *}$ Muhammad Yusra, ${ }^{2}$ Nur Afni Yunita \\ ${ }^{1,2}$ Faculty of Economics and Business Malikussaleh University \\ *Correspondence Author : nurafni.yunita@unimal.ac.id
}

\begin{abstract}
Implementation of Government Regulation Number 71 of 2010 concerning Government Accounting Standards brought changes in the presentation of government financial statements, which previously used cash-based accounting standards, to accrual-based accounting standards. Cash-based recognizes the recording of transactions and recognition occurs only when cash is out and cash in and does not record liabilities and assets at all. Accrual-based recording is believed to be able to produce financial reports that are more accurate and more reliable, comprehensive and relevant for decision making. In order to support the implementation of a good and competent accrual basis, supporting factors are needed such as human resources, organizational commitment, utilization of information and communication technology. The purpose of this study was to analyze the influence of human resources, organizational commitment, information and communication technology on the application of accrual-based accounting standards in the Lhokseumawe regency. The number of respondents in this study were 68 employees from the SKPK in Lhokseumawe regency, the research data was in the form of primary data with data analysis using multiple linear regression. The results showed that human resources, government commitment, information technology, and communication had an effect on the application of accrual-based accounting standards in Lhokseumawe regency. The number of respondents in this study were 68 employees from the SKPK in Lhokseumawe regency, the research data was in the form of primary data with data analysis using multiple linear regression. The results showed that human resources, government commitment, information technology, and communication had an effect on the application of accrual-based accounting standards in Lhokseumawe regency. The number of respondents in this study were 68 employees from the SKPK in Lhokseumawe regency, the research data was in the form of primary data with data analysis using multiple linear regression. The results showed that human resources, government commitment, information technology, and communication had an effect on the application of accrual-based accounting standards in the Lhokseumawe regency.
\end{abstract}

Keywords: Government Accounting Standards, Human Resources, Government Commitment, Information Technology, Communication

\section{INTRODUCTION}

The government financial management system in Indonesia has undergone many changes both organizationally, institutionally and managerially in the public sector, this is done to meet the need for better financial management. Changes in financial management can be exemplified as changes from a cash basis to an accrual basis. The change in the financial management system has caused the public sector management system to become more market-accommodating and flexible, which we know as the New Public Management 
(NPM). NPM adopters in Indonesia began with the enactment of Law number 17 of 2003, Law number 1 of 2004 and Law number 15 of 2004 concerning the provisions in one of the laws number 17 of 2003 is to require government accounting standards as the basis for preparing government financial statements. The law is strengthened by Government Regulation (PP) Number 71 of 2010 concerning changes to accrual-based Government Accounting Standards (SAP) as a substitute for Government Regulation (PP) number 24 of 2005. The stipulation of PP number 71 of 2010 means that the application of accrual-based government accounting standards has a legal basis. This means that the government has an obligation to immediately implement new government accounting standards, namely accrual-based government accounting standards (Safitri, 2017). The stipulation of PP number 71 of 2010 means that the application of accrual-based government accounting standards already has a legal basis. This means that the government has an obligation to immediately implement new government accounting standards, namely accrual-based government accounting standards (Safitri, 2017). The stipulation of PP number 71 of 2010 means that the application of accrual-based government accounting standards already has a legal basis. This means that the government has an obligation to be able to immediately implement new government accounting standards, namely accrual-based government accounting standards (Safitri, 2017).

The application of Government Accounting Standards (SAP) brought changes in the presentation of government financial statements which previously used cash-based accounting standards to change to accrual-based accounting standards. Cash-based recognizes the recording of transactions and recognition occurs only when cash is out and cash in and does not record liabilities and assets at all. While the accrual basis records and recognizes all transactions when they occur and records all assets and liabilities. Therefore, using accrual-based recording is believed to be able to produce financial reports that are more accurate and more reliable, comprehensive and relevant for decision making.

Accrual-based has the advantage of being able to demonstrate accountability for the use of all resources and managing assets and liabilities, being able to show funding and meeting cash needs for all organizational activities, enabling evaluation of the organization's ability to fund activities and fulfill obligations and commitments and allow evaluation of related organizational performance, cost and efficiency of activities.

But on the other hand, accrual-based is very constrained by the complexity of the system and the need for human resources who are more skilled in accounting (Suharso, 2016). This limitation is supported by problems in the field obtained from the results of the initial investigation through interviews with the ASN (State Civil Apparatus) of Lhokseumawe regency in 2021 at random. The findings found that the complexity in inputting data was the biggest obstacle, the transaction data were so numerous and detailed, recognizing every transaction that had to be recorded and reporting it into financial statements which were very complicated and took no time. The perceived problems are also reinforced by the use of technology in making financial reports. The many features in the reporting application sometimes break the concentration when doing financial reporting. 
Communication between subordinates and superiors is also considered to be one of the problems. Ineffective communication creates problems in the financial reporting process.

Based on some of the problems above, it is necessary to research on the Management of Accrual-based Accounting Standards Application in the Lhokseumawe Regency to realize its success. The purpose of this study is to analyze the extent to which the influence of determination of the factors that influence the application of accrual-based in the Lhokseumawe regency. Factors in research are proxied through human resources, organizational commitment, information and communication technology.

Scott (2008), Institutional Theory is a new institutional approach in studying organizational sociology. Theoretical sources come from cognitive theory, cultural theory, as well as phenomenology and ethnomethodology. There are three elements of analysis that build institutions although there are several elements that are dominant. However, these elements combine with each other, they come from different perspectives on the nature of social reality and social order in earlier sociological traditions. Furthermore, Scott (2008) explains the existence of the three pillars in a new approach from an institutional perspective. First, the pillar of regulation. It works in the context of rules, monitoring and sanctions. It has to do with the capacity to enforce rules, and provide rewards and punishments. This approach is closer to enforcement through informal and formal mechanisms. Development will provide opportunities as well as boundaries for individuals who work through the pillars of repression and restriction. Thus, individuals in this organization will be seen as a context that will maximize profits. Therefore, these institutions are often also referred to as regulatory agencies and rational choice institutions. Second, the normative pillar. In this view, norms produce evaluative perceptions and affirm the social responsibility of life. This pillar includes values and norms. Norms are useful for guiding individuals what goals they want to achieve, and how to achieve them. Therefore, this section is often referred to as normative institutions and historical institutions. This is often referred to as original institutional theory. Third, the cultural-cognitive pillar.

According to Andriyani (2017) in Erawati and Kurniawan (2018), human resources are the ability to carry out the tasks and responsibilities given by providing adequate education, training, and experience. In good regional financial management, all organizations must have quality human resources, supported by educational and training backgrounds, and have experience in the financial sector. The function of human resources is as a driving force of the organization in an effort to realize the vision and mission of the organization. With competent human resources, it will be easier to implement SAP accrual basis, because if there is no HR application, SAP accrual basis will not be implemented properly.

Organizational commitment is a state of an employee who sided with an organization and its goals and intends to maintain membership. Robbins (2008) in Erawati and Kurniawan (2018) argues that organizational commitment is a condition of individuals who have organizational characteristics and want to maintain their membership in the organization. High organizational commitment will create a sense of belonging (sense of belonging) for 
workers to the organization. The better the organizational commitment to the local government can improve the quality in the successful implementation of SAP accrual basis.

According to Rahman (2015) in Erawati and Kurniawan (2018) information technology can be interpreted as a technology used to process data, including processing, obtaining, compiling, storing, and manipulating data in various ways to produce quality information, namely relevant information., accurate and timely, which is used for personal, business, or government purposes and is strategic information for decision making. The function of information technology is to assist humans in creating, changing, storing and communicating information. Communication will determine the success of achieving the goals of implementing public policy. Faradila (2013) states that communication between the central government and local governments is needed on an ongoing basis to regulate and implement new standards. Therefore, several policies and socialization must be prepared so that the implementation of the new Government Accounting Standards can run well.

\section{IMPLEMENTATION METHOD}

This study uses a qualitative descriptive, with the object of research being the City Apparatus Work Unit (SKPK) brought by the local government of Lhokseumawe regency total 34 SKPK. Respondents in the study were the Head of Section of each SKPK and employees of the finance department who run the Regional Management Information System (SIMDA) application. The limitation of respondents is due to choosing competent parties who are directly involved in reporting and policies for preparing government financial reports. So that the results obtained truly reflect the actual situation in the field as a purity in research. The type of data used is primary data by using structured questions posed to respondents. The data collection method used isThe technique of collecting questionnaires is then processed using several statistical tests, namely data quality tests consisting of validity and reliability tests, classical assumption tests consisting of normality tests, multicollinearity tests, heteroscedasticity tests, and linearity tests, hypothesis tests consisting of t-tests. and F test as well as the coefficient of determination. Descriptions of operational variables can be seen in table 1, and the research framework can be seen in Figure 1 as follows:

Table 1. Variable Operation

\begin{tabular}{ll}
\hline \multicolumn{1}{c}{ Variable } & \multicolumn{1}{c}{ Indicator } \\
\hline Human Resources & 1. Integrity \\
2. Competence & 3. Loyalty \\
4. Rewards \\
5. Motivation \\
6. Organizational culture \\
Source: Erawati and Kurniawan (2015)
\end{tabular}




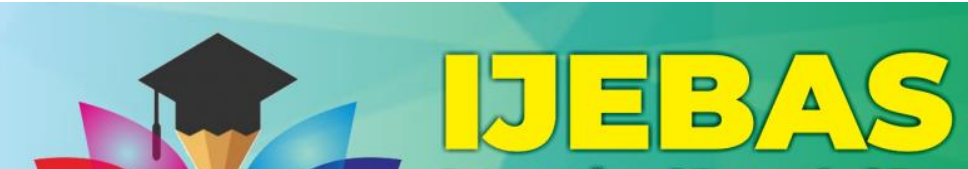

Intemational joumal of Economic, Business,

Organizational Commitment

1. Have the readiness of the main commitment to the task, readiness of discipline and responsibility in the implementation of SAP

2. Have readiness to carry out public service and public administration tasks by utilizing Government Accounting Standards

3. Have moral responsibility, commitment, integrity and transparency of Government Accounting Standards development in supporting the optimization of local government tasks

Source: Erawati and Kurniawan (2015)

\begin{tabular}{|c|c|}
\hline \multirow[t]{2}{*}{ Communication } & $\begin{array}{l}\text { 1. Policies and procedures that are } \\
\text { socialized }\end{array}$ \\
\hline & $\begin{array}{l}\text { 2. Clear instructions, } \\
\text { evaluation }\end{array}$ \\
\hline
\end{tabular}

3. The existence of communication facilities and infrastructure for internal parties

4. The existence of communication facilities and infrastructure for external parties

Source: Ismet (2018)

Accrual-based

implementation
SAP 1. Completeness of the presentation of accrual-based financial statements

2. The preparation of financial statements contains value, quality information to users

3. SKPK's vision and mission include the success of accrual-based implementation

4. SKPK provides facilities and infrastructure to support the achievement of accrual-based Government Accounting Standards

5. The involvement of the leadership and all human resources in the implementation to accrual-based evaluation.

Source: Erawati and Kurniawan (2015) 


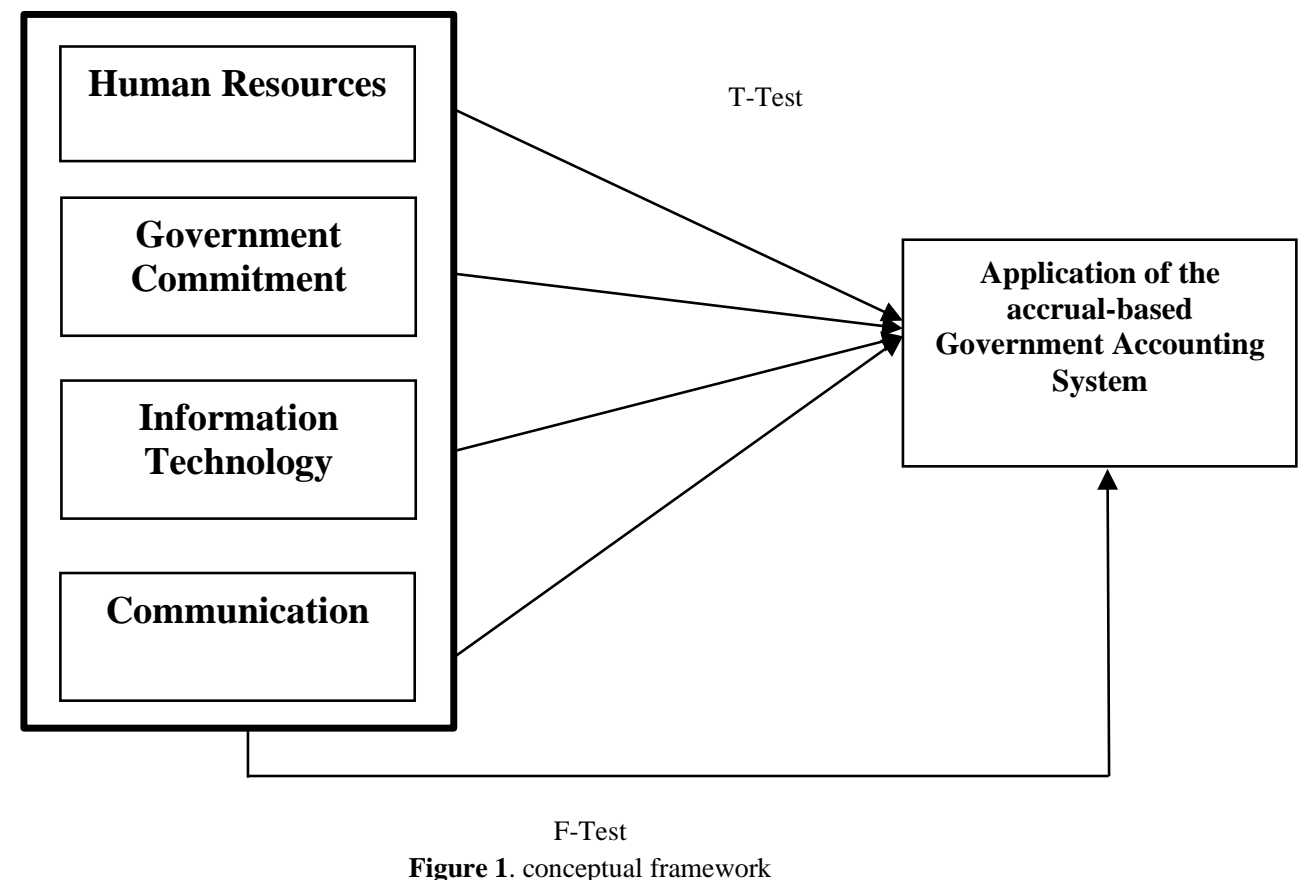

\section{RESULTS AND DISCUSSION}

\subsection{RESEARCH OBJECT PROFILE}

The Regional Apparatus Work Unit or SKPK is the executor of executive functions that must coordinate so that government administration runs well. SKPK is a local government agency that is responsible for the field of tasks borne by a Public Service Agency (BLU). The SKPK is responsible for the administration of government which consists of the regional secretariat, regional offices, regional agencies, sub-districts, police and civil service according to the needs of the region. The SKPK in the city of Lhokseumawe is attached in Table 2. below.

Table 2. SKPK Lhokseumawe

\begin{tabular}{ll}
\hline No. & \multicolumn{1}{c}{ SKPK Kota Lhokseumawe } \\
\hline 1 & Sekretariat Daerah Kota Lhokseumawe \\
2 & Sekretariat Dewan Perwakilan Rakyat Kota Lhokseumawe \\
3 & Sekretariat Baitul Mal Kota Lhokseumawe \\
4 & Sekretariat Majelis Adat Aceh Kota Lhokseumawe \\
5 & Sekretariat Majelis Pendidikan Daerah \\
6 & Sekretariat Majelis Permusyawaratan Ulama \\
7 & Dinas Kelautan Perikanan, Pertanian dan Pangan \\
8 & Dinas Kependudukan dan Pencatatan Sipil \\
9 & Dinas Kesehatan Kota Lhokseumawe \\
10 & Dinas Komunikasi, Informasi dan Persandian
\end{tabular}


11 Dinas Lingkungan Hidup

12 Dinas Pekerjaan Umum dan Perumahan Rakyat

13 Dinas Pemberdayaan Masyarakat dan Gampong

14 Dinas Pemberdayaan Perempuan, Perlindungan Anak, Pengendalian Penduduk dan Keluarga Berencana

15 Dinas Pemuda, Olahraga dan Pariwisata

16 Dinas Penanaman Modal, Pelayanan Terpadu Satu Pintu dan Tenaga Kerja

17 Dinas Pendidikan dan Kebudayaan

18 Dinas Perhubungan

19 Dinas Perindustrian, Perdagangan, Koperasi dan Usaha Kecil Menengah

20 Dinas Sosial

21 Dinas Syariat Islam dan Pendidikan Dayah

22 Dinas Pertanahan

23 Badan Kepegawaian dan Pengembangan Sumber Daya Manusia

24 Badan Kesatuan Bangsa dan Politik

25 Badan Penanggulangan Bencana Daerah

26 Badan Pengelolaan Keuangan Daerah

27 Badan Perencanaan Pembangunan Daerah

28 Badan Pertanahan

29 Inspektorat Kota Lhokseumawe

30 Kecamatan Muara Satu

31 Kecamatan Muara Dua

32 Kecamatan Banda Sakti

33 Kecamatan Blang Mangat

34 Satuan Polisi Pamong Praja dan Wilayatul Hisbah

\section{Source: Lhokseumawe Regency Archives}

\subsection{DATA QUALITY TEST}

This study uses validity and reliability tests in measuring data quality. Validity test of 68 respondents and 39 questions found thatall have rcount above rtable (0.242). The results of the validity test showed that all the questions in the questionnaire on 4 independent variables and the dependent variable were declared valid. Question items are said to be valid because rcount $>$ rtable with a significant value of $5 \%$ for each question. This shows that each of the questionnaire questions is valid and can be trusted to collect research data. Likewise for the results of the reliability test, it was found that the results of the Croanbach alpha of the Human Resources variable (X1) were $0.756>0.60$, the organizational commitment variable $(\mathrm{X} 2)$ was $0.760>0.60$, the information technology variable (X3) was $0.767>0.60$, the communication variable $(\mathrm{X} 4)$ was 0.776 , and the variable for the 
application of accrual basis accounting standards $(\mathrm{Y})$ was $0.722>0.60$. Thus, all items of the question variables above have a value greater than 0.60 . So it can be concluded that the questionnaire in this study has met the requirements of reliability (reliable).

\subsection{CLASSIC ASSUMPTION TEST}

\subsubsection{NORMALITY TEST}

From the normality test, it can be seen that the Kolmogorov-Smirnov value in this study was 0.094 with the Asymp level. Sig. (2-tailed) of 0.200 is greater than 0.05 . Therefore, it can be oncluded that the residual data are normally distributed.

\subsubsection{MULTICOLLINEARITY TEST}

Multicollinearity test can be seen from the value of VIF (variance inflation factors) and tolerance value. If the tolerance value is $>0.10$ or equal to the $\mathrm{VIF}$ value $<10$, it means that there is no correlation between the independent variables or there is no multicollinearity between the independent variables. The tolerance value for the human resources variable (X1) is $0.424>0.10$ and the VIF value is $2.359<10$. So that the human resource variable is stated that there is no multicollinearity.

Meanwhile, the tolerance value for the organizational commitment variable (X2) is $0.505>0.10$ and the VIF value is $1.979<10$. So that the organizational commitment variable is stated that there is no multicollinearity.

\subsubsection{HETEROSCEDASTICITY TEST}

The heteroscedasticity test aims to test whether there is an inequality of variance from the residual of an observation to another observation in the regression model. A good regression model is if the variance of the residuals from one observation to another is different (heteroscedasticity). The statistical test that can be used to test heteroscedasticity is the Glejser test. If the test result is above the significant level ( $p>0.05)$, it means that there is no heteroscedasticity, but if it is below the significant level $(p<0.05)$ then there is heteroscedasticity (Ghozali, 2016).

The results of the study show that the significant probability value for the human resource variable (X1) is $0.238>0.05$, so it can be concluded that the human resource variable (X1) does not have heteroscedasticity. In the organizational commitment variable (X2), the probability value is $0.532>0.05$, so it can be concluded that the organizational commitment variable (X2) does not have heteroscedasticity.

The significant probability value for the information technology variable (X3) is 0.324 $>0.05$ so it can be concluded that the information technology variable (X3) does not have heteroscedasticity. Likewise, the significant probability value for the communication variable (X4) is $0.122>0.05$, so it can be concluded that the communication variable (X4) does not have heteroscedasticity. 


\subsection{LINEARITY TEST}

The following are the results of multiple linear analysis using the help of the SPSS version 22 program, which can be seen in Table 3 below

Table 3. Results of Multiple Linear Analysis

\begin{tabular}{|c|c|c|c|c|c|}
\hline \multirow[b]{2}{*}{ Model } & $\begin{array}{l}\text { Unsta } \\
\text { Coeff }\end{array}$ & $\begin{array}{l}\text { lardized } \\
\text { ients }\end{array}$ & $\begin{array}{c}\text { Standardize } \\
\mathrm{d} \\
\text { Coefficient } \\
\mathrm{s} \\
\end{array}$ & \multirow[b]{2}{*}{$\mathrm{T}$} & \multirow[t]{2}{*}{ Sig. } \\
\hline & B & $\begin{array}{l}\text { Std. } \\
\text { Error }\end{array}$ & Beta & & \\
\hline 1 (Constant) & 1.106 &, 510 & & 2,169 & ,034 \\
\hline Human Resources &, 179 & , 193 & ,293 & $\begin{array}{r}2,84 \\
5\end{array}$ & $\begin{array}{r}0.01 \\
4\end{array}$ \\
\hline $\begin{array}{l}\text { Organizational } \\
\text { Commitment }\end{array}$ & ,262 &, 105 & ,264 & $\begin{array}{r}2,49 \\
0\end{array}$ & $\begin{array}{r}0.01 \\
6\end{array}$ \\
\hline Information Technology & ,466 & , 128 & ,455 & $\begin{array}{r}3,65 \\
3\end{array}$ & .001 \\
\hline Communication & , 106 &, 172 & ,269 & $\begin{array}{r}2,46 \\
1\end{array}$ & $\begin{array}{r}0.01 \\
4\end{array}$ \\
\hline
\end{tabular}

Source : SPSS Processing Data 22,2 021

Based on Table 3, multiple linear regression equations can be formed as follows:

\section{$\mathrm{Y}=1.106+0.179 \times 1+0.262 \times 2+0.466 \times 3+0.106 \times 4+e$}

From the multiple linear regression equation above, it can be explained that the regression coefficient value of the human resource variable $\mathrm{X} 1$ of 0.179 indicates a positive relationship, meaning that every decrease in human resources $\mathrm{X} 1$ by 1 point on the Likert scale causes the application of accrual basis accounting standards $Y$ to increase by 0.179 in a positive direction. assuming other variables are constant. The regression coefficient value of the X2 organizational commitment variable of 0.262 shows a positive relationship, meaning that every increase in X2 organizational commitment by 1 point on a Likert scale causes the application of accrual basis accounting standards $Y$ to increase by 0.262 in a positive direction with the assumption that other variables are constant.

The regression coefficient value for information technology variable X3 of 0.466 indicates a positive relationship, meaning that every increase in information technology X3 by 1 point on a Likert scale causes the application of accrual basis accounting standards $Y$ to increase by 0.466 in a positive direction with the assumption that other variables are constant. As well as for the regression coefficient value of the communication variable $\mathrm{X} 4$ of 0.106 , it shows a positive relationship, meaning that every increase in X4 communication by 1 point on a Likert scale causes the application of accrual basis accounting standards $Y$ to increase by 0.106 in a positive direction with the assumption that other variables are constant. 


\subsection{Hypothesis Testing Results}

To see the relationship of each independent variable to the dependent variable. If the results of research and data processing found a significance value of $t>0.05$, then the hypothesis is rejected. This means that the independent variable partially has no effect on the dependent variable. However, if the significance value of $t<0.05$, then the hypothesis is accepted. The results of hypothesis testing can be seen in Table 4 below:

Table 3. Hypothesis Testing Results

\begin{tabular}{|c|c|c|c|c|c|}
\hline \multirow[b]{2}{*}{ Model } & \multicolumn{2}{|c|}{$\begin{array}{l}\text { Unstandardized } \\
\text { Coefficients }\end{array}$} & $\begin{array}{r}\text { Standardized } \\
\text { Coefficients } \\
\end{array}$ & \multirow[b]{2}{*}{$\mathrm{T}$} & \multirow{2}{*}{ Sig. } \\
\hline & $\mathrm{B}$ & $\begin{array}{l}\text { Std. } \\
\text { Error }\end{array}$ & Beta & & \\
\hline 1 (Constant) & 1.106 &, 510 & & 2,169 & 034 \\
\hline Human Resources &, 179 & ,193 & ,293 & 2,845 & $\begin{array}{r}0.01 \\
4\end{array}$ \\
\hline $\begin{array}{l}\text { Organizational } \\
\text { Commitment }\end{array}$ &, 262 &, 105 & ,264 & 2,490 & $\begin{array}{r}0.01 \\
6\end{array}$ \\
\hline Information Technology & ,466 &, 128 &, 455 & 3,653 & .001 \\
\hline Communication & ,106 &, 172 & ,269 & 2,461 & $\begin{array}{r}0.01 \\
4\end{array}$ \\
\hline
\end{tabular}

Source : SPSS Processing Data 22,2021

The influence of the human resource variable X1 on the application of accrual basis accounting standards Y. From the coefficients table obtained a significance value of $\mathrm{t}=0.014$ $<0.05$, the hypothesis $\mathrm{H} 1$ is accepted. This means that the human resource variable partially affects the application of accrual basis accounting standards. From the results of statistical analysis, it can be said that human resources have an effect on the application of accrual basis accounting standards in Lhokseumawe City SKPD. This is because in the application of accrual basis accounting standards in the city government of Lhokseumawe, the human resources that are owned are considered adequate in the field of accounting, and their application has also been applied by the Lhokseumawe City government and absolutely must be carried out according to PP. 71 year 2010.

Erawati and Kurniawan (2018) state that the readiness of local governments is seen from the quality of human resources, here it can be seen that existing human resources have not fully mastered the accrual basis because in using regional management information systems, training on how to apply it still needs to be done. According to Putri (2017) Human Resources function as the main supporting pillar as well as the driving force of the organization in an effort to realize the vision and mission as well as the goals of the organization. The failure of local government human resources in understanding and applying accounting logic will have an impact on errors in the financial statements made and inconsistency of reports with standards set by the government. 
The organizational commitment variable has significance value $\mathrm{t}=0.016<0.05$ then the hypothesis $\mathrm{H} 2$ is accepted. This means that the organizational commitment variable partially affects the application of accrual basis accounting standards. This proves that employees and superiors in the Lhokseumawe Regency SKPD have a competent organizational commitment to support the successful application of accrual basis accounting standards in accordance with PP. 71 of 2010. Based on the PP, all government agencies, both central and regional, starting in 2015 are obliged to implement accrual basis accounting standards, so that it has become the goal of the Lhokseumawe Regency SKPD to participate in implementing it. The higher the organizational commitment of the SKPD and financial staff, the better and more successful in the application of accrual basis accounting standards.

According to Putri and Silvi (2015) committed government employees will work optimally because they want the success of the organization where they work. Government employees who have a high commitment because they think that the organization is a place to work and live will have an understanding or appreciation of the preparation of financial statements in accordance with government accounting standards. This is also in accordance with Susanti and Agusti's (2015) statement which states that organizational commitment is a part related to employee performance in relation to their work, in the sense of the desire to carry out tasks in terms of regional financial management even though regional financial regulations often change. Local governments that have high organizational commitment will use the information they have to give to each member of the organization in order to further increase the success to be achieved. The better the organizational commitment to the local government, the better the quality in the successful implementation of the accrual basis of Government Accounting Standards (Riyanto, and Agus, P. 2015).

In line with the previous variable, the information technology variable obtained a significance value of $t=0.001<0.05$, so the hypothesis $\mathrm{H} 3$ was accepted. This means that information technology variables partially affect the application of accrual basis accounting standards. In the application of accrual basis accounting standards, the Lhokseumawe Regency SKPD has prepared adequate information technology for the successful application of accrual basis accounting standards. The Lhokseumawe Regency has also realized that all financial systems and records have been carried out online or computerized. With adequate information technology this will help employee performance in achieving maximum results. Employees can also use and utilize the existing devices properly, and the hardware used has been supported by the latest software that makes it easier for employees to do their jobs. From the results of interviews conducted at the Lhokseumawe Regency SKPD, the application used in financial recording is the SIMDA application (Regional Management Information System). So that information technology is very influential in the effort to apply accrual basis accounting standards.

According to Susanti and Agusti (2015) information technology support is one of the factors that affect the implementation of Government Accounting Standards. Erawati and Kurniawan (2018) also state that the application of accrual-based accounting standards to local governments will speed up the process of recording, presenting, analyzing and 
reporting local government finances because accounting computer applications were created to authorize accounting transactions into a report and report analysis for support decision making regarding the financial condition of an accounting period. Technology is one component that affects government accounting standards in the accrual-based public sector.

The Communication variable has a significance value of $t=0.014<0.05$, so the hypothesis $\mathrm{H} 4$ is accepted. This means that the organizational commitment variable partially affects the application of accrual basis accounting standards. The application of accrual basis accounting standards is an obligation and mandate of law for every government agency, both central and local, so that accrual basis accounting standards have been communicated since the issuance of PP Number 71 of 2010 and the transition process to the use of accrual basis accounting standards has been carried out until the 2014 fiscal year. (Susanti and Agusti, 2015). Thus, good or bad communication that is implemented or carried out in Lhokseumawe Regency, the application of accrual basis accounting standards must continue to be carried out according to PP. 71 year 2010, this causes communication to have no effect on the application of accrual basis accounting standards in Lhokseumawe Regency SKPD. Susanti and Agusti (2015) also explain that communication is the main tool used in order to carry out continuous interaction to achieve goals. Communication really determines the success of achieving the goals of implementing public policy.

\section{CONCLUSIONS AND SUGGESTIONS}

\subsection{CONCLUSION}

Based on the tests and results that have been carried out regarding the influence of human resources, organizational commitment, information and communication technology on the application of accrual basis accounting standards at SKPK Lhokseumawe, the researchers can conclude that human resources, government commitment, information technology, and communication have an effect on the application of accrual-based accounting standards in the Lhokseumawe Regency.

\subsection{SUGGESTION}

Based on the results of the discussion and conclusions regarding the influence of human resources, organizational commitment, information and communication technology on the application of accrual basis accounting standards in Lhokseumawe Regency SKPD, the following suggestions can be put forward:

1. SKPK Lhokseumawe to maintain and strive to improve human resources, commitment in an organization, adequate information technology in order to facilitate the work process, and improve communication between the central government to local governments and local governments to realize employees so that the application of government accounting standards in accordance with PP Number 71 in 2010.

2. Further researchers need to add questions in the questionnaire so that the research is more in-depth, adding categories of respondents such as all employees in the finance 
department of each SKPK, adding or replacing newer independent variables that are thought to have an effect on the application of accrual basis government accounting standards.

\section{REFERENCES}

Erawati, T., \& Kurniawan, D. 2018. The application of an accrual-based accounting system: a study of the behavioral aspect. Journal of Economics and Business, 21(2), 313-332.

Faradillah, 2013, Analysis of Local Government Readiness in Applying Government Accounting Standards (PP No. 71 of 2010), E-Journal of the University of Palangkaraya, Palangkaraya.

Ghozali, Imam. 2016. Application of Advanced Multivariate Analysis with SPSS Program. Semarang: Diponogoro University Publishing Agency.

Indonesia. 2010. Government Regulation of the Republic of Indonesia Number 71 of 2010 concerning Government Accounting Standards. Jakarta.

Indonesia. 2003. Law of the Government of the Republic of Indonesia Number 17 of 2003 concerning State Finance. Jakarta

Indonesia. 2004. Law of the Government of the Republic of Indonesia Number 1 of 2004 concerning the State Treasury. Jakarta.

Indonesia. 2004. Law - Law of the Government of the Republic of Indonesia Number 15 of 2004 concerning Auditing the Management and Accountability of State Finances. Jakarta.

Putri, DU 2017. The Influence of Human Resource Competence, Organizational Commitment and Communication Functions on the Implementation of AccrualBased Government Accounting Standards in Regional Work Units in Bandung City. National Seminar on Accounting and Business (SNAB), Faculty of Economics, Widyatama University.

Riyanto, and Agus, P. 2015. Accrual-Based Local Government Accounting. Printing 1. Yogyakarta: Student Library.

Robbins, Stephen, P. 2008, Organizational Behavior Tenth Edition, PT Index Group Gramedia, Jakarta.

Safitri, D. 2017. Factors Affecting the Application of Accrual-Based Government Accounting Standards (Study on the Bengkalis District Government Skpd). Journal of Accounting (Accounting \& Finance Research Media), 5(2), 174-189.

Scott, WR 2008. Institutions and Organizations: Ideas and Interests. 3rd ed. Sage Publications, Los Angeles, CA.

Silfi, A., Azlina, N., \& Iznillah, ML 2015. The Effect of Quality of Human Resources, Organizational Commitment, Information Technology, and Communication on Government Readiness in Applying Accrual-Based Government Accounting 
Analysis Of Determination Of The Implementation Accrual-Based Accounting Standards In

Lhokseumawe Regency

DOI: $10.54443 /$ ijebas.v1i2.82

Standards (Empirical Study on the Government of Indragiri Hilir Regency). Online Journal of Students of the Faculty of Economics, University of Riau, 2(2).

Suharso.2016. Government Accounting Base in Indonesia. Accessed viahttps://www.klikharso.com/2016/03/basis-acuntansi-governmental-di.html on 25 January 2020.

Susanti, TF, \& Agusti, R. 2015. Analysis of Factors Affecting Accrual-Based Sap Implementation in Pelalawan Regency Government. Journal of Economics, 23(3), 11-24. 